\title{
Effect of spray drying conditions on antioxidants activity, flavonoids and total phenolic compounds of stevia rebaudiana
}

\author{
Chaparro-Hernández, I. ; Rodríguez-Ramírez, J. ${ }^{\text {a* }}$, Méndez-Lagunas, L. a Barriada- \\ Bernal, L.G. ${ }^{\text {a,b }}$ \\ a Instituto Politécnico Nacional CIIDIR Oaxaca, Hornos 1003 Sta. Cruz Xoxocotlán, Oaxaca 71230, \\ México. \\ b Consejo Nacional de Ciencia y Tecnología, Hornos 1003 Sta. Cruz Xoxocotlán, Oaxaca 71230, \\ México
}

*E-mail of the corresponding author: jrodrigr@ipn.mx

\begin{abstract}
In this work the spray drying of the fresh stevia leaves aqueous extract without encapsulating agents was carried out. The effect of the inlet air temperature $\left(160-200{ }^{\circ} \mathrm{C}\right)$ and the feed flow rate $(2-3 \mathrm{~kg} / \mathrm{h})$ on the total phenolic content, the total flavonoid content and the antioxidant capacity were evaluated using Folin-Ciocalteau, aluminum chloride and DPPH methods respectively. The inlet air temperature had a significant effect on all parameters evaluated that showed a decrease when increasing the inlet air temperature, the feed flow rate had a significant effect on total flavonoids content and the antioxidant capacity, by increasing the feed flow rate the inhibition of the DPPH radical decreased and the total flavonoid content increased. The treatment at $160{ }^{\circ} \mathrm{C}$ and $3 \mathrm{~kg} / \mathrm{h}$ retained highest total flavonoid content and the antioxidant capacity.
\end{abstract}

Keywords: Phenolic compounds, stevia, spray drying, antioxidant capacity 


\section{Introduction}

Several families of compounds with nutraceutical y functional properties have been described in the stevia polyphenolic family. These compounds include phenolic compounds $^{[1]}$, flavonoids ${ }^{[2]}$ and tannins ${ }^{[3]}$.

Spray drying is a continuous operation technology commonly used to obtain high concentrations of soluble compounds ${ }^{[4]}$. For plant extracts, spray drying has been used to obtain products with high physical, chemical and microbiological stability, low storage costs and long shelf life $\mathrm{f}^{[5]}$.

This research aimed to evaluate the effect of the inlet air temperature and the feed flow (FF) rate of the spray drying of fresh stevia leaves aqueous extracts on the total phenolic compounds (TPC) and the antioxidant capacity (AA).

\section{Materials and Methods}

\subsection{Raw material}

Fresh leaves of S. rebaudiana variety Morita II were collected from an organic crop in Oaxaca, Mexico (Fig.1).

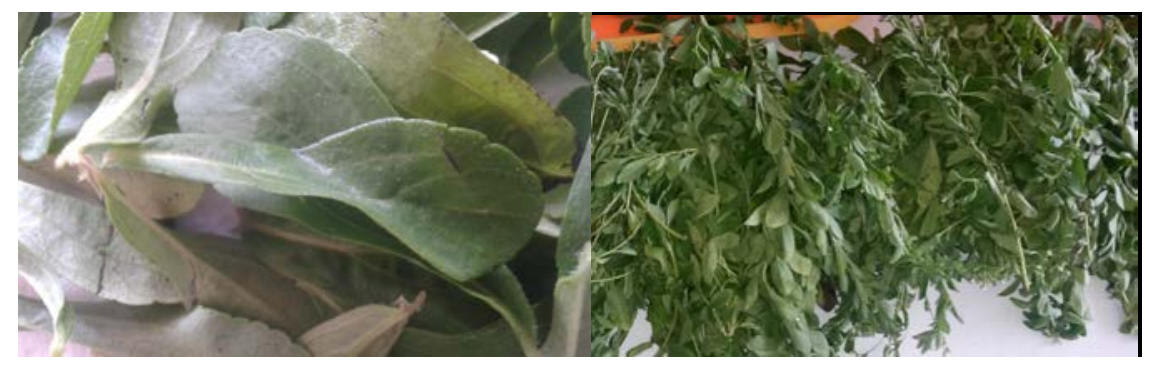

Fig. 1 Fresh stevia leaves.

\subsection{Aqueous extract}

Distilled water at $80{ }^{\circ} \mathrm{C}$ was added to the fresh leaves in 5:1 v/w ratio, followed by ultrasonic extraction at $25{ }^{\circ} \mathrm{C}$. Afterward, it was left at $25{ }^{\circ} \mathrm{C}$ for $48 \mathrm{~h}$ in the dark. The extract was filtered using a mesh sieve (pore size $0.149 \mathrm{~mm}$ ).

\subsection{Spray drying}

A Mobile Minor concurrent flow spray dryer (Niro Copenhagen, Denmark), equipped with a pneumatic pulse rotary atomizer (TS-Minor, M02/B), was used. The atomization rate was set at 23,000 rpm, and the drying air flow was $84 \pm 2 \mathrm{~kg} / \mathrm{h}$. 


\subsection{Moisture content and total solids}

Moisture contents was determined according to the AOAC ${ }^{[6]}$ method 934.01. The total solids of the extract, expressed as gram of dry matter per liter $\left(g_{d m} / L\right)$, was determined according the $\mathrm{AOAC}^{[6]} 990.19$ method.

\subsection{Determination of total phenolic content}

Phenolic compounds were extracted with methanol acidified with hydrochloric acid at $1 \%$ $(\mathrm{v} / \mathrm{v})$.The total phenolic content was analyzed by the Folin-Ciocalteu method, as described by Periche et $\mathrm{al}^{[7]}$.

\subsection{Determination of antioxidant capacity}

An $80 \%$ methanol solution was used for extraction of antioxidant compounds. The antioxidant capacity (\%) was measured with the DPPH method according to Shukla et al ${ }^{[8]}$.

\subsection{Determination of total flavonoid content}

An $80 \%$ methanol solution was used for extraction of flavonoids. The aluminum chloride colorimetric method was used, according to Kumazawa et al ${ }^{[9]}$. The absorbance was read at $510 \mathrm{~nm}$. Standard de quercetin was used as references. Flavonoids were expressed as quercetin equivalent per litre (mg QE/mL).

\subsection{Conversion of concentration units}

In order to compare the effect of the drying conditions on the content of total phenolic compounds, the total flavonoid content and the antioxidant activity, the measurement units were expressed on a dry basis, using Eqs. (1) and (2):

$C_{T}=\frac{C_{C} \times V_{e x}}{W_{d l}}$

$\mathrm{W}_{\mathrm{dl}}$ was calculated using Eq. (2):

$W_{d l}=w_{f l}\left(1-X_{w b}^{f}\right)$

\subsection{Statistical analysis}

All the analysis were performed on triplicates. A $2^{2}$ factorial design, with three central points, was applied to evaluate the effect of inlet air temperature $\left(\mathrm{T}_{\text {in }}\right)\left(160\right.$ and $\left.200{ }^{\circ} \mathrm{C}\right)$ and FF rate (2 and $3 \mathrm{~kg} / \mathrm{h}$ ) on the total phenolic content, antioxidant activity and total flavonoids content. Data analysis was done using ANOVA, and a response was performed with Statistica software Ver. 7. 


\section{Results and discussion}

The concentration of phenolic compounds in the fresh leaves was $77.00 \pm 0.59 \mathrm{GAE} / \mathrm{g}_{\mathrm{dl}}$, which was higher than that reported in other works. Periche et $\mathrm{al}^{[7]}$ reported an average content of $44.40 \pm 1.04 \mathrm{GAE} / \mathrm{g}_{\mathrm{d} l}$ while Lemus-Mondaca et al ${ }^{[11]}$ obtained $0.29 \pm 0.02$ $\mathrm{GAE} / \mathrm{g}_{\mathrm{dl}}$.

The drying process significantly influenced $(\mathrm{p}<0.05)$ the phenolic compounds content. In all drying treatment (Table 1) the phenolic compound content decreased when the drying temperature was raised. The powders showed an average phenolic compounds loss of $57 \%$. The FF rate did not have a significant effect on TPC ( $>0.05)$. The results obtained in this work contrast with those obtained by Periche et $\mathrm{a}^{[7]}$. (2015), who dried stevia extracts by convection and lyophilized reporting an increased total phenolic content as temperature increases. This inconsistency could be due to direct exposure of the extract of ground fresh stevia leaves to the spray drying conditions. Therefore, the phenolic compounds were more exposed during the spray drying as opposed to when the whole leaf is dried, in which the phenolic compounds are protected in the vacuoles ${ }^{[12]}$.

Table 1. Total phenolic, flavonoids and antioxidant capacity content.

\begin{tabular}{lcccc}
\hline $\begin{array}{c}\text { Temperature } \\
{ }^{\circ} \mathrm{C}\end{array}$ & $\begin{array}{c}\text { Feed flow } \\
\text { rate } \\
\mathrm{kg} / \mathrm{h}\end{array}$ & $\begin{array}{c}\text { Phenolic } \\
\text { compounds } \\
\text { mg GAE/gdl }\end{array}$ & $\begin{array}{c}\text { Flavonoids } \\
\text { mg QE/gd }\end{array}$ & $\begin{array}{c}\text { Antioxidant } \\
\text { capacity } \\
\%\end{array}$ \\
\hline Fresh leaves & 2 & $77 \pm 0.59$ & $170.45 \pm 0.61$ & $93.66 \pm 0.55$ \\
200 & 3 & $40.90 \pm 0.57$ & $110.47 \pm 0.48$ & $88.68 \pm 0.64$ \\
200 & 2 & $41.48 \pm 0.78$ & $117.26 \pm 1.08$ & $76.93 \pm 0.30$ \\
160 & 3 & $49.93 \pm 0.91$ & $117.10 \pm 0.24$ & $86.36 \pm 0.68$ \\
160 & $21.21 \pm 0.11$ & $124.68 \pm 0.58$ & $90.13 \pm 0.78$ \\
\hline
\end{tabular}

The flavonoid concentration in the fresh leaves was $170.45 \pm 0.61 \mathrm{mg} \mathrm{QE} / \mathrm{g}_{\mathrm{d} l}$. In all drying treatments the flavonoid concentration decreased (Table 1).

For instance, Lemus-Mondaca et al ${ }^{[12]}$ reported, in fresh samples, an lower amount of 0.89 $\pm 0.02 \mathrm{mg} \mathrm{QE} / \mathrm{g}_{\mathrm{dl}}$. The flavonoids concentration was affected by the drying process $(\mathrm{p}<0.05)$, showing a decrease with the increase in temperature and an increased when FF decrement. This results could be because flavonoids are sensitive to oxidation and thermal degradation during spray drying ${ }^{[5]}$.

The inlet air temperature and the FF rate significantly impacted $(p<0.05)$ on the antioxidant capacity. The highest antioxidant capacity was observed at the lowest temperature $\left(160^{\circ} \mathrm{C}\right)$ 
and the highest FF (3 kg/h). This results were similar to Georgetti et al ${ }^{[13]}$ and Krishnaiah et $\mathrm{al}^{[14]}$ who reported similar behavior for spray-dried soybean extract and Morinda citrifolia.

\section{Conclusions}

Spray drying is an efficient technology for the preservation of the antioxidant compounds of the fresh stevia leaves aqueous extract, even without the use of encapsulating agents. The antioxidant capacity of the final product ranged from 76 to $90 \%$. The treatment at $160{ }^{\circ} \mathrm{C}$ and $3 \mathrm{~kg} / \mathrm{h}$ retained highest total flavonoid content and the antioxidant capacity Therefore, the aqueous stevia leaves extract could be considered as a natural source of antioxidants, with prospects to be considered as a food complement.

\section{Nomenclature}

C Total phenolic content, total flavonoid content or $\mathrm{mg} / \mathrm{g}_{\mathrm{dl}}$ antioxidant activity concentration

$\begin{array}{lll}\text { FF } & \text { Feed flow rate } & \mathrm{kg} / \mathrm{h} \\ \mathrm{V} & \text { Water volume } & \mathrm{mL} \\ \mathrm{W} & \text { Weight of the leaves } & \mathrm{g}_{\mathrm{dl}} \\ \mathrm{X} & \text { Moisture content } & \mathrm{g}_{\mathrm{w}} / \mathrm{g}\end{array}$

Subscripts

$\begin{array}{cl}\text { C } & \begin{array}{l}\text { Concentration obtained from the calibration } \\ \text { curve }\end{array} \\ \text { dl } & \text { Anhidra leaves } \\ \text { ex } & \text { Used for extraction } \\ \text { fl } & \text { Fresh leaves } \\ \text { in } & \text { Inlet } \\ \text { dm } & \text { Dry matter } \\ \text { T } & \text { Total } \\ \text { wb } & \text { Water basis }\end{array}$

Superscripts

f Fresh leaves

\section{References}

[1] Shukla, S.; Mehta, A., Mehta, P.; Bajpai, V. K.. Antioxidant ability and total phenolic content of aqueous leaf extract of Stevia rebaudiana Bert. Experimental and Toxicologic Pathology 2012, 64(7-8),807-811. 
[2] Abou-Arab, A. E.; Abou-Arab, A. A.,; Abu-Salem, M. F. Physico-chemical assessment of natural sweeteners steviosides produced from Stevia rebaudiana bertoni plant. African Journal of Food Science 2010, 4(5), 269-281.

[3] Gasmalla, M.; Yang, R.; Amadou, I.; Hua, X. Nutritional Composition of Stevia rebaudiana Bertoni leaf: effect of drying method. Tropical Journal of Pharmaceutical Research 2014, 13(1), 61

[4] Taylor, P.; Souza, C. R. F.; Oliveira, W. P., Souza, C. R. F.; Oliveira, W. P. Powder Properties and system behavior during spray drying of Bauhinia forficata link extract. Drying Technology 2007, 6(24),37-41.

[5] Anandharamakrishnan, C.; Ishwarya, S. P. Spray Drying Technique for Food Ingredient Encapsulation; Wiley Blackwell, 2015

[6] A.O.A.C. Official Methods of Analysis of the Association of Official Analytical Chemists. Arlingtong, Virginia. 1984

[7] Periche, A.; Castelló, M. L.; Heredia, A.; Escriche, I. Influence of drying method on steviol glycosides and antioxidants in Stevia rebaudiana leaves. Food Chemistry 2015, 172, 1-6.

[8] Shukla, S.; Mehta, A., Mehta, P.; Bajpai, V. K. Antioxidant ability and total phenolic content of aqueous leaf extract of Stevia rebaudiana Bert. Experimental and Toxicologic Pathology 2012, 64(7-8), 807-811.

[9] Kumazawa, S.; Hamasaka, T.; Nakayama, T. Antioxidant activity of propolis of various geographic origins. Food Chemistry 2004, 84, 329-339.

[10] Méndez-Lagunas L.L.; Rodríguez-Ramírez J.; Cruz-Gracida M.; Sandoval-Torres S.; Barriada-Bernal G. Convective drying kinetics of strawberry (Fragaria ananassa): effect on antioxidant activity, anthocyanins and total phenolic content, Food Chemistry 2017, 230, 174-181,2017

[11] Lemus-Mondaca, R.; Ah-Hen, K.; Vega-Gálvez, A.; Honores, C.; O. Moraga, N. Stevia rebaudiana leaves: effect of drying process temperature on bioactive components, antioxidant capacity and natural sweeteners. Plant Foods for Human Nutrition 2016, 71(1), 49-56.

[12] Bruneton, J. Farmacognosia, Fitoquímica, Plantas Medicinales (Vol. 1); Acribia: España, 2001

[13] Georgetti, S. R.; Casagrande, R.; Souza, C. R. F.; Oliveira, W. P.; Fonseca, M. J. V. Spray drying of the soybean extract: Effects on chemical properties and antioxidant activity. LWT - Food Science and Technology 2008, 41(8), 1521-1527

[14] Krishnaiah, D.; Sarbatly R.; Nithyanandam R. Microencapsulation of Morinda citrifolia L. extract by spray-drying. Chemical Engineering Research and Design 2012, 90(5), 26-36 